\title{
SCHOOL DROPOUT: AN ENQUIRY IN THE RURAL AREAS OF PALGHAR TALUKA
}

DR. VINITA PIMPALE

Associate Professor

Department of Commerce

R. A Podar College of Commerce and Economics

Email: vinitakris@gmail.com

9820621140

\section{Introduction}

India has the second largest educational system in the world after China wherein more than one million primary and secondary school cater to the educational needs of the Indian children. Within the total educational system, Primary and secondary schools form the main bulk of institution/schools of India. Schooling has been enforced for all children under fourteen. The government spending on education is being upraised to six per cent of the GDP. Incentives are being given to schools with best student and teacher attendance. The Government sponsored Sarva Shiksha Abhiyan (Universal Elementary Education), efforts on increasing enrolment rates and reducing drop-out rates. There is extensive occurrence of poor quality of education at the primary and secondary levels across the country. Even though children are promoted to the next grades based on sheer attendance, they are unable to comprehend material taught to them three grades below. But then more students are going to school.

The Maharashtra state government, right from its formation on 1st May, 1960, committed itself to planned development of primary education. The planning process in the country started in the year 1951 with the first Five Year Plan. The programme of educational development was envisaged under the Second Plan. The Third Five-Year-Plan provided for the essential needs of free, universal and compulsory education in primary stage of standard I to IV. The Fourth plan provided not only for a quantitative expansion of primary education but also aimed at qualitative improvement in the system, methods and facilities of education. For the first time in the country, Maharashtra state published a Policy Statement of Educational Reconstruction in February 1970. The statement announced a programme of long-term perspective planning for educational reconstruction linked with social and national goals. It suggested that the transformation of the educational system was needed so as to 
make education relevant to the needs and aspirations of the people through appropriate development of all stages of education. Development could take place through equality of educational opportunity, qualitative development of education co-ordination of educational planning with the planning of other sectors of development, and through the reorganization of teacher education, educational administration and the passage of suitable legislation.

The Sixth Five-Year Plan pointed out the crucial role of education in the process of economic development and how it was the fundamental need for creating human capital of trained, competent work force for implementing the process of development. Its approach was to ensure essential minimum education to all children up to the age of 14 years within the next ten years, particularly giving attention to school drop outs and to those groups which were in danger of being left behind because of their special circumstances. During the Sixth Plan period, a primary school was opened in every village in the State having a population of about 200 and above.

The Seventh Plan's objective was to universalize primary education in the 14-year age-group children, to reduce dropout rate, especially amongst girls. The objective of opening a new primary school within a radius of $1.5 \mathrm{~km}$. in every area with a population of 200 within was achieved during the Seventh Plan.

The new policy of universalization of primary education was given priority in the Eighth Plan and a sum of Rs. 404.48 crore was spent on primary education. The enrolment of children belonging to 6-14 age-group was 84 per cent by the end of the Plan.

In Maharashtra, primary education in the rural areas is entirely the responsibility of the zilla parishads. Based on the recommendations of the Naik Committee, Maharashtra adopted the panchayati raj pattern, which deviated from the model laid down by the Balwant Rai Mehta study team, by making the district body, the zilla parishad, a strong executive body at the district level rather than the block level body.

In India, we have three different types of schools, namely schools that follow state syllabus, schools that follow central syllabus and schools that follow International curriculum. Hence, at any class level, we end up with students who have different levels of academic knowledge. Coming to the rural villages, students who come from economically backward classes are obliged to opt for Government run schools due to their financial constraints. The Government run schools teach in vernacular medium. For the purpose of present case study, Zilla Parishad Primary schools in Palghar district are considered. The students in Zilla Parishad Primary schools are from a weak economic background. The present study deals with various factors that influence the dropouts of students in Zilla Parishad Primary schools. 


\section{Review of literature}

According to NSSO data, 13 out of every 100 Indians between 5-29 years did not attend school because they did not consider education 'necessary'. The following chart better describes the reasons for not going to school

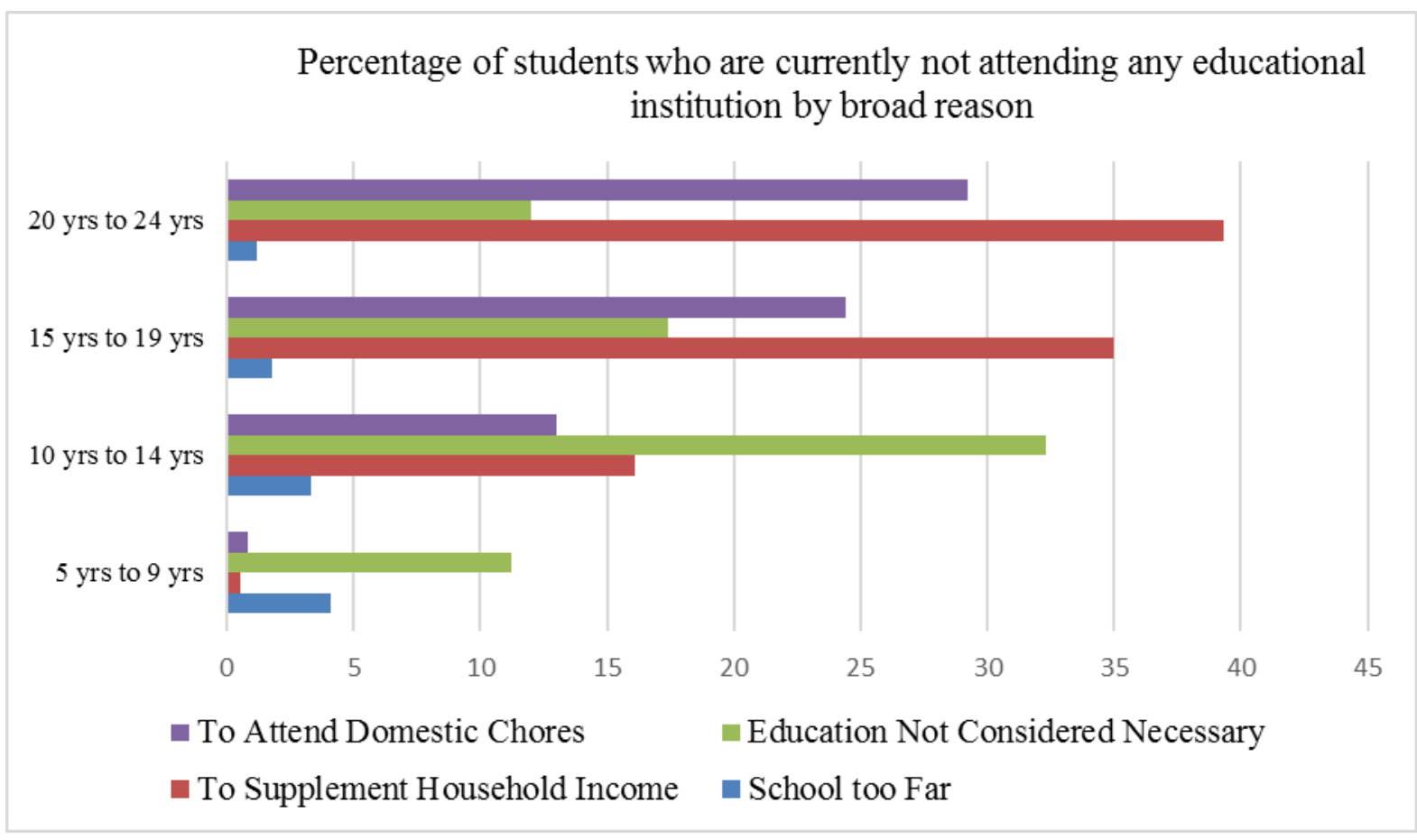

Source: NSSO

\section{Research Methodology}

Palghar is the new progressive district of the Maharashtra state. It is the northern district of Konkan region. Palghar district is very important agriculture district as being nearer to Mumbai. Topographically it has much diverse condition.ie. hilly zone, saline zone, plateau zone and characterised by highly erratic rainfall. $55 \%$ of the area of the district is covered by forest. Six talukas of the district are tribal.

The purpose of this study is to investigate the factors and root causes leading student dropout. It is felt that this research will enable the administration to "identify" high and at risk students and student groups (e.g., individual students or entire student groups more likely to dropout than other student's/students groups). The research questions examined in this paper are: To what extent is student dropout due to intrinsic (related to the student) factors and to what extent is it due to extrinsic (non-student) factors? (e.g., study methods and materials) 


\section{Objective}

The objective of this study is to examine the "reasons why" student's dropout.

The Main Objectives was to examine the dropout in the Palghar district with regards to

- To study the societal and parental factor that contribute towards enrolment and retention of primary school children.

The study was carried out on a sample of 100 children (including 50 boys and 50 girls identified and designated as school drop-outs).

School drop-outs as defined in this study referred to those 'subjects who had not attended the school continuously during the past one year or more'.

The sample was collected by covering school in the rural areas of Palghar district in Maharashtra. The children were in age group between 5-14 years. They were drop-outs in the grades between 1 and 10 respectively

\section{Sample Selection}

\begin{tabular}{|c|c|c|c|c|c|c|c|c|c|c|c|}
\hline $\begin{array}{c}\text { Total/ } \\
\text { Rural/ } \\
\text { Urban }\end{array}$ & $\begin{array}{c}\text { Area in } \\
\text { Square } \\
\text { Kilometre }\end{array}$ & $\begin{array}{c}\text { Number of } \\
\text { households }\end{array}$ & \multicolumn{2}{|c|}{$\begin{array}{c}\text { Total population (including } \\
\text { institutional and houseless } \\
\text { population) }\end{array}$} & \multicolumn{3}{|c|}{$\begin{array}{c}\text { Population in the } \\
\text { age-group 0-6 }\end{array}$} \\
\hline Total & $1,186.04$ & 112,253 & 481,236 & 251,991 & 229,245 & 61,415 & 31,310 & 30,105 & 334,391 & 190,576 & 143,815 \\
\hline Rural & $1,140.47$ & 74,032 & 324,786 & 165,149 & 159,637 & 41,117 & 20,736 & 20,381 & 214,337 & 120,078 & 94,259 \\
\hline Urban & 45.57 & 38,221 & 156,450 & 86,842 & 69,608 & 20,298 & 10,574 & 9,724 & 120,054 & 70,498 & 49,556 \\
\hline
\end{tabular}

Source: Censes 2011

There are 31 primary schools existing in the Palghar taluka. Out of these some primary schools are attached with high schools also. On south boundary 3 primary schools are on south boundary of the Palghar i.e. in village Varkhunti and Kamare.

There are 12 high schools existing in the Palghar. In these different medium schools are there i.e. Marathi, Hindi, English, Gujrathi, Urdu and special children also. There are seven colleges in the municipal limit.

\section{Findings and Discussions}

The discontinuation of the education is a threatening signal to our educational system. To find out the possible reasons, parents, teachers and administrators have to be involved. 
This study reveals that numerous inter-related social, economic, school and cultural factors affect school dropout. The financial factors constrain parents more especially those who have lower socioeconomic status compared to those who have higher status. Parents with lower socio-economic status face difficulties to bear the expenses of their children's education. In addition, parents sometimes use the gender of their children to decide who gets more education so that children can give benefit in the future; in these circumstances male children eventually get more priority compare to female children.

Average literacy rate of Palghar is recorded in 2011 census 76.73 percent, of which male and female literacy was 75.62 and 62.73 respectively. It is observed that the rural female literacy level is low.

Chart 1: literacy rate

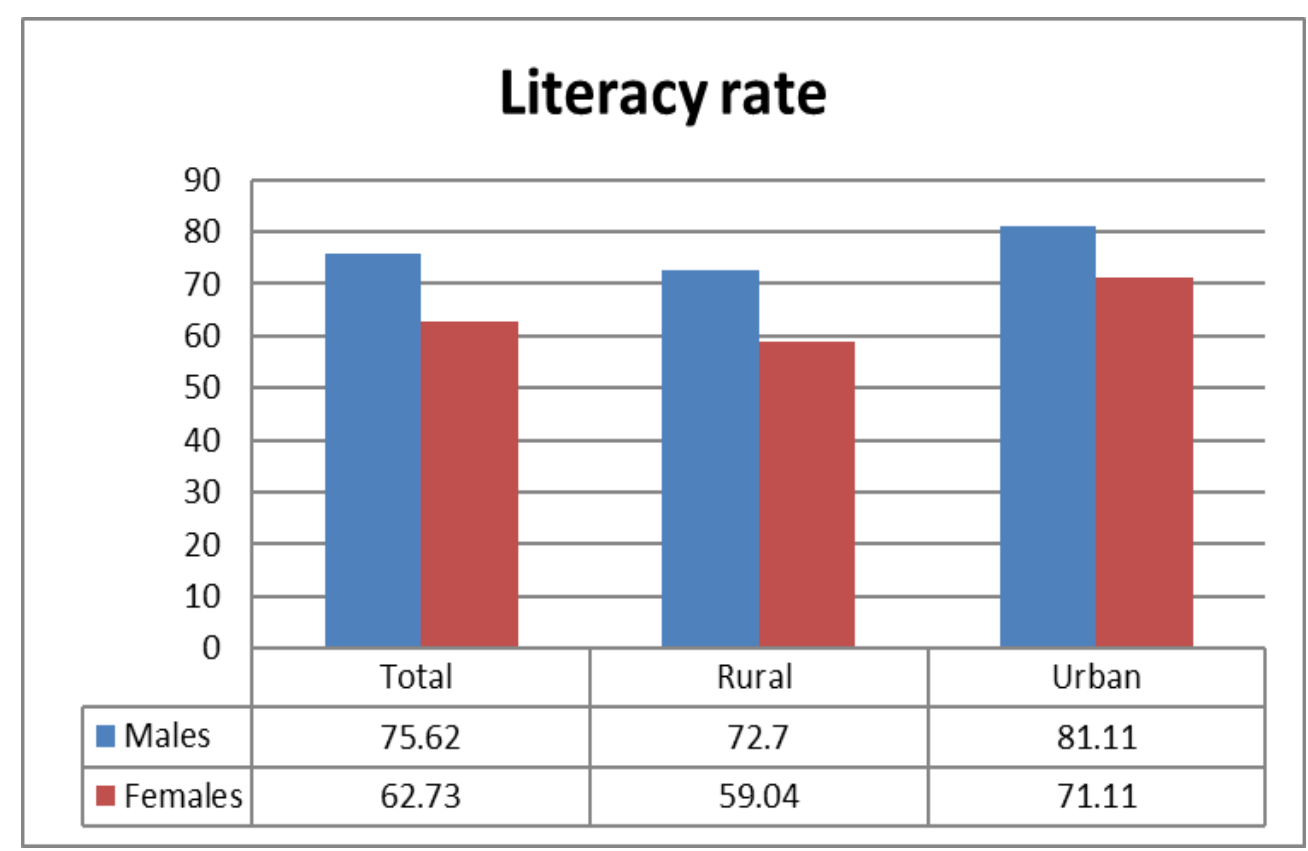

Source: Censes 2011

\section{Religion}

Table-1 gives religion-wise distribution of the family of the respondent. As per the data collected, the sample is predominantly $80 \%$ Hindu with Christian $12 \%$ and $8 \%$ Muslim families.

Table 1: Religion-wise distribution

\begin{tabular}{|l|l|l|}
\hline & & $\%$ \\
\hline Hindu & 80 & 80 \\
\hline
\end{tabular}




\begin{tabular}{|l|l|l|}
\hline Muslim & 08 & 08 \\
\hline Christian & 12 & 12 \\
\hline Total & 100 & \\
\hline
\end{tabular}

Educational status

Table 2: Educational level of Parents

\begin{tabular}{|l|l|l|}
\hline & & $\%$ \\
\hline Illiterate & 68 & $68 \%$ \\
\hline Literate & 32 & $32 \%$ \\
\hline S.S.C & 62 & $62 \%$ \\
\hline H.S.C & 29 & $29 \%$ \\
\hline Graduate & 9 & $9 \%$ \\
\hline Total & 100 & \\
\hline
\end{tabular}

It is revealed that out of the data collected $32 \%$ fathers were literate, $62 \%$ have just completed that SSC and 29\% are educated upto class HSC, 9\% have completed their Graduation of the remaining,

\section{Occupation}

Table 3: Occupation of Father

\begin{tabular}{|l|l|l|}
\hline & & $\%$ \\
\hline Farming & 57 & $57 \%$ \\
\hline Fishing & 2 & $2 \%$ \\
\hline Skill worker & 8 & $8 \%$ \\
\hline Service & 10 & $10 \%$ \\
\hline Business & --- & --- \\
\hline Total & 100 & \\
\hline
\end{tabular}

Table-3 reveals the occupational level of the respondents. It observed that the families are involved in farming on not only their land but they also work on other people farm. Some on 
them hire the land of local people, do farming for the whole year, and give $1 / 3$ of the output to the landowner. $57 \%$ engage in farming $2 \%$ are into fishing as the district is a taluka place there are service and business opportunities so we find nearly $10 \%$ of the respondents in government services.

Income

There is a significant link between poverty and a child's educational opportunities. One of the basic reason to move away from school is the financial constraints it was found that out of the entire $100 \%$ respondents there are people below the yearly income of one lac. These owners work as labours on some other people's farms.

Table 4: Income of Family

\begin{tabular}{|l|l|l|}
\hline & & \% \\
\hline Less Than $1,00,000$ & 25 & $25 \%$ \\
\hline $1,00,000$ to $2,50,000$ & 40 & $40 \%$ \\
\hline $2,50,000$ to $5,00,000$ & 34 & $34 \%$ \\
\hline above $5,00,000$ & 01 & $1 \%$ \\
\hline & & \\
\hline Total & $\mathbf{1 0 0}$ & \\
\hline
\end{tabular}

It is seen from Table 4 that $25 \%$ of the parents have an annual income between Rs. 100000 to 250000, $40 \%$ are in the income group less than Rs. 500000, 34\% have an income above Rs. 500,000 . The economic condition of the parents is the most significant factor in dropout student from Zilla Parishad School.

Physical approachability of schools

Though primary schools are functioning in almost every village, some remote villages remain poorly attended. For example, some villages in hill areas of Palghar are hardly accessible by State Transport buses or private vehicles in the rainy season so that teachers do not show up for a entire period. Inspection is inadequate and village residents dare not criticize for fear of being expelled. As regards lower secondary education, in spite of significant investments in 'extension schools' (primary schools offering lower secondary education), children in some remote areas are supposed to travel more than $10 \mathrm{~km}$. through the mountains. 
The table below shows the reasons for leaving schools before the completion of their education. It is quite evident that poverty is the dominant reason for dropping out of school. The poor economic condition of the parents often forces them to remove their ward from school and engage them in domestic activities or make them work.

Reasons expressed by respondents for school dropouts at the primary level

\begin{tabular}{|l|l|}
\hline Reasons & Percentage \\
\hline Household work & 88.33 \\
\hline Lack of parental guidance in studies & 86.66 \\
\hline Large family size & 82.50 \\
\hline Poor economic condition & 80.83 \\
\hline Failure in examination & 79.16 \\
\hline Lack of time for study & 67.50 \\
\hline Punishment by teachers & 53.33 \\
\hline Ill health & 53.33 \\
\hline Lack of interest in studies by the drop-out & 44.16 \\
\hline Lack of parental interest in continuation of studies & 40.00 \\
\hline Disliking for teachers & 18.33 \\
\hline Illiteracy of parents & 13.33 \\
\hline
\end{tabular}

Source: Data collected by researcher

\section{Recommendations}

Broadly stated, researchers have acknowledged that many factors influence dropping out of school, including the circumstances of schooling, individual behaviour characters, home situation, and the economic position within which students live.

From the foregoing results and conclusions of the study, the following recommendations emerge.

a) For increasing approachability to the school, the content of education must be applicable and suited to that society needs.

b) Discussion with the users of the educational services is vital to the acceptance of changes as per their requirement. 
c) Administrator should be aware of the importance of parents' attitude and what they expect from school for their children.

d) Bridge the cultural gap between parents and teachers.

\section{Conclusion}

The need to restrict dropout rates at the primary school education level cannot be exaggerated. Government policies outlined in the Sarva Shiksha Abhiyan (Universal Elementary Education) all point to desired outcomes for education. It could be a solution to involve the school principal and teachers to put in extra effort to improve the quality of learning as well as provide incentive for attending the school. This is challenging but possible and attainable task. There is a need to understand that only framing government policies could not attract students to class but the teachers should play a crucial role in educational development.

\section{Bibliography}

- Aggarwal, J.C., (1993), "Development and Planning of Modem Education", Vikas Publishing House Pvt. Ltd., 4th Ed., New Delhi.

- Choudhury, Amit (2006), "Revisiting Dropouts: Old Issues, Fresh Perspectives", Economic and Political Weekly, December 16.

- Desai, Uday (1991), "Determinants of Educational Performance in India: Role of Home and Family", International Review of Education, Vol. 37, No. 2 pp. 245- 265

- Harichandran D (1992), "Girls education in India: A situational analysis". Journal of Educational Planning and Administration 6(2): 179-192.

- Study Sponsored by Planning Commission, Govt. Of India Conducted by Indian Institute of Education. Dec (2014) - A study of the extent and causes of drop outs in primary schools in rural Maharashtra with special reference to girl drop-outs

- Sharma, Ruchita, Shubhangna Sharma and Shipra Nagar, (2007), "Extent of Female School Drop outs in Kangra District of Himachal Pradesh”, Journal of Social Science, 15(3): 201-204. 
- Rao, Mohan, M.J. (2000). "Migration of labour and school dropouts", Social Welfare, 47(6): $26-31$

- Zaidi SMIA (1991), "Problems of wastage in school education: Dropouts at elementary level". Journal of Educational Planning and Administration 5(2): http://mhrd.gov.in/sarva-shiksha-abhiyan reviewed on 25th march 2016

- Maharashtra Government Education Policies

- Panchyat samiti BDO office report 2011 